\title{
Volatility, financial constraints, and trade
}

\author{
by
}

\author{
Maria Garcia-Vega \\ Dep. Fundamentos del Analisis Economico I, Facultad de CC. Economicas y Empresariales, Campus de \\ Somosaguas, 28223, Madrid, Spain \\ and \\ Alessandra Guariglia ${ }^{*+}$ \\ School of Economics, University of Nottingham, University Park, Nottingham NG7 2RD, United Kingdom
}

\begin{abstract}
We construct a dynamic monopolistic model with heterogeneous firms to study the links between firms' idiosyncratic income volatility, the degree of financial constraints that they face, and their export market participation decisions. Our model predicts that more volatile companies are more likely to fail, need to be more productive to stay in the market, and are more likely to enter export markets. A further implication is that through market diversification, exports tend to stabilize firms' total sales. We test these predictions, using a panel of 9292 UK manufacturing firms over the period 1993-2003. The data provide strong support to our model.
\end{abstract}

*Corresponding author: TBA.

+ The authors are grateful for detailed comments on an earlier draft of this paper from Parantap Basu, Robert Hine, Maria del Pilar Montero, and participants at presentations at the European Trade Study Group 2006. Financial support from the Leverhulme Trust under Programme Grant F114/BF is also gratefully acknowledged. 


\section{Introduction}

A number of recent studies have focused on the causes of the rise in firm level volatility, which characterized US firms in recent years. For instance, Comin and Philipon (2005) argue that this increase is primarily due to more competition in product markets, which in turn might be due to deregulation, increases in R\&D investment, and higher use of debt and equity. Other papers have focused on the consequences of the rise in firm level volatility. For instance, Comin et al. (2006) document that the rise in firm turbulence explains about sixty percent of the rise in the high frequency volatility of wages. To the best of our knowledge, no study has looked at the effects of firm level volatility on firm survival and trade. This paper fills the gap. Specifically, we construct a dynamic monopolistic model with heterogeneous firms to study the links between firms' idiosyncratic uncertainty, the degree of financial constraints that they face, and their export market participation decisions. Our model can be seen as an extension of Melitz' (2003) model, in which firm level volatility is included as an additional element of firm heterogeneity, in addition to productivity. Our model predicts that more volatile companies are more likely to fail, need to be more productive to stay in the market, and are less likely to enter export markets. A further implication is that through market diversification, exports tend to stabilize firms' total sales. We test these predictions, using a panel of 9292 UK manufacturing firms over the period 1993-2003. The data provide strong support to our model.

The rest of the paper is laid out as follows. In Section 2, we outline our model, both in the closed and in the open economy case. Section 3 describes our data. Section 4 tests the main implications of the model, and Section 5 concludes.

\section{The model}

\subsection{Demand}

We assume that the economy has two sectors: one is characterized by a numeraire good, and the other by differentiated products. The preferences of a representative consumer are given by the following intertemporal utility function: 
$U=\int_{0}^{\infty}\left(x_{0}+\log Y\right) e^{-\hat{r} t} d t$

where $\hat{r}$ is the discount factor, $x_{0}$ is the consumption of the numeraire good, and $Y$ is an index of consumption of the differentiated products. As in Dixit and Stiglitz (1977), $Y$ reflects the consumer's taste for varieties, and can be written as:

$\mathrm{Y}=\left[\int_{0}^{\mathrm{n}}\left(\mathrm{y}_{\mathrm{z}}\right)^{\rho} \mathrm{dz}\right]^{\frac{1}{\rho}}$ and $0<\rho<1$

where $y_{z}$ is the quantity of variety $z$ of the differentiated product demanded by the consumer, $n$ is the mass of firms in the stationary competitive equilibrium, and $\alpha=1 /(1-\rho)$ is the elasticity of substitution among varieties. As shown by Dixit and Stiglitz (1977), the consumer's behavior can be modeled considering the set of varieties of the aggregate good $Y$ consumed, with aggregate price $P_{Y}=\int_{0}^{n} p_{z}^{1-\alpha} d z$. In this set-up, the aggregate demand for any of the varieties of the differentiated product is given by $y=\frac{p^{-\alpha}}{P_{Y}} E$, where $E$ is aggregate expenditure, and $p$ is the price of the good (see Grossman and Helpman, 1991, for a similar approach).

\subsection{Production}

We assume that firms are heterogeneous. Firms differ in their productivity and in their income volatility. Firms have different levels of productivity, denoted by $\varphi \in[0, \infty)$. As in Melitz (2003), productivity affects the firm's variable cost function. More productive firms have a lower marginal cost than their less productive counterparts. Each good is produced only with labour. The technology to produce each of the differentiated goods is given by: $l(\varphi)=I+y / \varphi$, where $l$ is labour, and $I$ is a fixed cost in every period. This leads to the standard pricing rule $p(\varphi)=1 /(\rho . \varphi)$, where the numerator represents the common wage rate that we normalize to 1 . Firms with high levels of efficiency will charge lower prices and obtain higher revenues. 
We introduce a new element of heterogeneity among firms: their idiosyncratic income volatility, denoted with $\sigma \in[0, \infty)$. Volatility is related to an exogenous demand firm-specific shock that firms face each period, immediately after they have chosen their prices and quantities, and prior to their decision problem of the next period. Specifically, in each period, the firm's income is given by $z_{t}(\sigma) p(\varphi) y(\varphi)$, where $z_{t}$ is the demand shock, which is distributed normally with mean one and standard deviation $\sigma$. Note that if $\sigma=0$ for all firms, the model specializes to Melitz's (2003) case. We consider that productivity and income volatility are both exogenous, independent, and constant parameters. This assumption implies that neither productivity nor income volatility are decision variables for the company ${ }^{1}$, and that, as in Hopenhayn (1992), in the competitive equilibrium, prices are deterministic. Before entry, firms draw their initial productivity $g(\varphi)$, and volatility $h(\sigma)$ from a common distribution with continuous cumulative distribution given respectively by $G(\varphi)$ and $H(\sigma)$.

\subsection{The firm's problem}

We assume that the firm faces a cash-in advance constraint: in each period, it requires the bank to finance its fixed $\operatorname{cost}^{2}$. Companies repay the loan at an interest rate denoted with $r$, that differs among firms depending on the risk associated with the investment. As in Cooley and Quadrini (2001), we assume that there are only one period debt contracts signed with the bank. If the firm defaults on the debt, the bank liquidates the firm, and the company immediately exits the industry. The firm's profits can be written as:

$$
\Pi_{t}\left(\varphi, \sigma, z_{t}\right)=z_{t} p(\varphi) y(\varphi)-\left[\frac{y(\varphi)}{\varphi}+[1+r(\varphi, \sigma)] I\right]
$$

\footnotetext{
${ }^{1}$ In other models, productivity and volatility are considered as endogenous variables. For instance, in Comin and Mulai (2005), firms choose how much to invest in R\&D, and because R\&D investments are risky, they increase both the firm's productivity and the volatility of its productivity. Since our analysis only focuses on income volatility, it is reasonable to assume that both productivity and volatility are exogenous.

${ }^{2}$ We assume that the fixed cost of production is identical among firms. Therefore, in the model, the firm does not choose its optimal amount of debt. In order to simplify the model, we consider that debt is the same for all firms and that it is independent of their productivity.
} 
where $\Pi_{t}\left(\varphi, \sigma, z_{t}\right)$ represents the profit of a firm of type $(\varphi, \sigma)$, at period $t$ after the realization of its shock $z_{t}$.

We assume that risk-neutral banks perfectly observe the firm's characteristics. As in Cooley and Quadrini (2001), we consider that banks issue funds at an interest rate $r$, such that the expected repayment from the loan is equal to the repayment of a riskless loan. This is summarized in the following Equation:

$\left(1+r_{0}\right) I=(1+r(\varphi, \sigma)) \mathrm{I}(1-\delta(\varphi, \sigma, r))+C(\sigma) \delta(\varphi, \sigma, r)$ where $(1+r) I>C$.

The left-hand side of Equation (3) gives the return of the loan at the riskless interest rate $r_{0}$. The right hand side of the equation says that with probability $1-\delta$ the company can repay its debts, and with probability $\delta$, it goes bankrupt. In the case of bankruptcy, the bank gets the firm's collateral $(C)$, which depends negatively on the firm's income volatility ${ }^{3}$.

The firm's probability of bankruptcy, is given by the following cumulative distribution:

$\delta(\varphi, \sigma, r)=\int_{-\infty}^{\underline{z}(\varphi, r)} f(z, \sigma) d z=\int_{-\infty}^{\underline{z}(\varphi, r)} \frac{1}{\sigma \sqrt{2 \pi}} e^{\frac{-(z-1)^{2}}{2 \sigma^{2}}} d z$

The probability of bankruptcy given by Equation (4) involves a threshold shock, denoted by $\underline{z}(\varphi, r)<1$. We assume that a firm will exit the market as soon as it experiences an income shock below the threshold. We assume that the threshold shock solves the following equation: $\underline{z} p(\varphi) y(\varphi)-\frac{y(\varphi)}{\varphi}-(1+r) I=0$.

\footnotetext{
${ }^{3}$ It is assumed that the company defaults and goes bankrupt if it is unable to repay its loan. This holds independently on the amount of the loan. There is therefore no possibility to renegociate the loan. However, the bank is more likely to recover a higher part of the loan when the firm defaults, if the loan is relatively small. Since more volatile firms are more likely to obtain more extreme returns, when they go bankrupt, it is more likely that they ask for larger loans. For this reason we assume that from the point of view of the bank, the collateral is a negative function of the company volatility.
} 
The next proposition, proved in Appendix 1, gives the relationship between the firm's volatility and its probability of bankruptcy.

Proposition 1: Controlling for productivity, the collateral to debt ratio, and the interest rate, firms with high idiosyncratic income volatility have a higher probability of bankruptcy than firms with low volatility. Consequently, it is more costly for these firms to obtain external finance.

The model suggests that firms characterized by higher income volatility will have a higher probability of bankruptcy. This channel drives to an increase in the costs of accessing external funding. This implication is consistent with the empirical result of Minton and Schrand (1999), who find that cash flow volatility is positively related with the costs of accessing external capital.

As in Hopenhayn (1992) and in Melitz (2003), in every period an incumbent firm makes two decisions: whether to leave the industry or to stay, and in the latter case, how much to produce. The value of a firm of type $(\varphi, \sigma)$ at period $t$ after the realization of its shock in the stationary competitive equilibrium is denoted with $v_{t}\left(\varphi, \sigma, z_{t}\right)$, and is given by:

$$
\begin{aligned}
& v_{t}\left(\varphi, \sigma, z_{t}\right)=\Pi_{t}\left(\varphi, \sigma, z_{t}\right)+(1-\delta(\varphi, \sigma)) \max \left\{0, E_{t}\left[v_{t+1}\right]\right\}= \\
& =\Pi_{t}\left(\varphi, \sigma, z_{t}\right)+\sum_{s=t+1}^{\infty}\left(1-\delta((\varphi, \sigma))^{s-t} \Pi_{s}(\varphi, \sigma, 1)=\Pi_{t}\left(\varphi, \sigma, z_{t}\right)+\frac{1}{\delta(\varphi, \sigma)} \Pi(\varphi, \sigma, 1) .\right.
\end{aligned}
$$

The firm will stay in the industry if its expected future value is positive, in the stationary competitive equilibrium, i.e. if $E_{t}\left[v_{t+1}\right]>0$. This is equivalent to saying that its expected future profits in each period are positive, i.e. that $\Pi(\varphi, \sigma, 1)>0 .{ }^{4}$ Let $\varphi_{\min }$ be the level of productivity for which the firm obtains zero profit when its volatility is zero ${ }^{5}$, and for which the income shock is equal to one. The following condition, proved in Appendix 1,

\footnotetext{
${ }^{4}$ In order to simplify the notation, we write $\Pi(\varphi, \sigma)$ instead of $\Pi(\varphi, \sigma, 1)$.
} 
shows the characteristics in terms of productivity and volatility of the firms that can obtain a loan and therefore stay in the market.

Zero-profit condition: For any level of productivity $\varphi \in\left[\varphi_{\min }, \infty\right)$, there exits a function $s$ satisfying $s(\varphi)=\sigma$, such that $\Pi(\varphi, s(\varphi))=0$. Thus, if $\varphi>s(\varphi)$, the firm cannot obtain a loan and exits the market; while if $\varphi<s(\varphi)$, the firm remains in the market.

Graphically the zero-profit condition can be represented as in Figure 3. This leads to the following Proposition:

\section{INSERT FIGURE 3 HERE}

Proposition 2: Firms characterized by high income volatility need to have a high level of productivity; otherwise they are forced to exit the market. However, there is no correlation between volatility and productivity for low levels of volatility. Firms with low volatility can have either a high or a low productivity level and stay in the market.

The intuition behind Proposition 2 is that volatility is costly. Therefore, only firms with high productivity levels can counter the high cost associated with volatility, and obtain on average positive profits.

Let us denote with $f_{e}$ the entry cost, and with $E_{t}^{a}\left[v_{t+1}\right]$ the expected ex-ante firm value which is given by $E_{t}^{a}\left[v_{t+1}\right]=P_{i n} \sum_{s=t+1}^{\infty}(1-\bar{\delta})^{s} \bar{\Pi}_{s}$, where $P_{i n}$ is the ex-ante probability of successful entry, $\bar{\delta}$ is the average probability of bankruptcy, and $\bar{\Pi}$ is the average exante profit ${ }^{6}$. New firms will enter in the industry until the expected ex-ante firm's value

\footnotetext{
${ }^{5}$ In this case, the interest rate that the company has to pay is the riskless interest rate and the model specializes to Melitz's model.

${ }^{6}$ The ex-ante probability of successful entry is equal to $P_{i n}=\operatorname{Pr} o b\left(\varphi>\varphi_{\min }\right) \operatorname{Pr} o b\left(\sigma<f(\varphi) / \varphi>\varphi_{\min }\right)=\left[1-G\left(\varphi_{\min }\right)\right][1-H(s(\varphi))]$.
} 
net of the entry cost is zero (Free entry condition). The following Equation will therefore hold:

$E_{t}^{a}\left[v_{t+1}\right]-f_{e}=0$

As in Melitz (2003), a stationary equilibrium is defined by constant aggregate variables over time and free entry for firms into the industry. We show in Appendix 1 that such an equilibrium satisfies the zero cut-off profit condition, the free entry condition, and an aggregate stability condition that requires that the mass of successful entrants in each period exactly replaces the mass of incumbents who are hit by a bad shock and exit. In the equilibrium the distribution of firms can therefore be represented as follows:

$\mu(\varphi, \sigma)=\left\{\begin{array}{cl}\frac{g(\varphi) \cdot h(\varphi)}{P_{i n}} & \text { if } \varphi \geq \varphi_{\min }, \text { and } \sigma \leq s(\varphi) \\ 0 & \text { otherwise. }\end{array}\right.$

\subsection{Open economy model}

Effects of trade on the probability of bankruptcy

We now assume that there are two identical countries that trade the varieties of $Y$. Trade involves two types of costs. Firstly, there is a sunk entry cost into the foreign market, $f_{e}^{x}$. As in Melitz (2003), we assume that every period, the firm pays the amortized per-period portion of this cost, denoted by $I^{x}$. As in the closed economy framework, every period, exporters borrow the fixed cost from the bank. Secondly, there is a variable cost per unit of product that is transported. As typically assumed in the literature, this variable cost takes the form of an iceberg cost, so that for one unit of a good to arrive to the final

The average probability of bankruptcy is given by $\bar{\delta}=\int_{-\infty}^{\bar{z}(\bar{\sigma})} \frac{1}{\bar{\sigma} \sqrt{2 \pi}} e^{\frac{-(z-1)^{2}}{2 \bar{\sigma}^{2}}} d z$, where $\bar{\sigma}$ is the average volatility, and $\bar{\varphi}=\int_{\varphi_{\min }}^{\infty} \varphi \cdot \frac{g(\varphi)}{[1-G(\varphi)]} g(\varphi)\left(\int_{0}^{s(\varphi)} \frac{h(\sigma)}{[1-H(s(\varphi))]} d \sigma\right) d \varphi$ is the average productivity. 
destination, $\tau>1$ units of the good need to be shipped. While prices in the domestic market (denoted with $p^{d}(\varphi)=\frac{1}{\rho . \varphi}$ ) are the same as before, exporters set higher prices in the foreign market, due to the increase in the marginal cost. These are given by: $p^{x}(\varphi)=\frac{\tau}{\rho . \varphi}$. The profits of an exporter in the domestic and the foreign market are respectively given by:

$\Pi_{t}^{d}=z_{t}^{d} p^{d} y^{d}-\frac{y^{d}}{\varphi}-\left(1+r^{T}\right) I, \quad$ and $\quad \Pi_{t}^{x}=z_{t}^{x} p^{x} y^{x}-\frac{y^{x}}{\varphi}-\left(1+r^{T}\right) I^{x}$

where $r^{T}$ is the interest rate paid by an exporter on its total loan, $I+I^{x}$, and $z_{t}^{x}$ is the income shock in the foreign market. We assume that the shock in the foreign market is normally distributed with mean one and variance $\sigma^{x}$. As in the closed economy model, the domestic shock, has mean one and variance $\sigma^{d}$. When firms export, their probability of bankruptcy and their access to external funds change. If national and international shocks are correlated, we can aggregate both shocks and model them as a total income shock that is normally distributed with variance $\sigma^{T}$ (given by the sum of the national and international income variances plus two times the covariance between the two shocks). The probability of bankruptcy of an exporter is therefore given by the cumulative normal distribution shown in the following expression (which has mean two and total variance $\left.\sigma^{T}\right)$ :

$\delta^{T}\left(\varphi, \sigma^{T}, r^{T}\right)=\int_{-\infty}^{\underline{z}^{T}\left(\varphi, r^{T}\right)} f^{T} d z=\int_{-\infty}^{\underline{z}^{T}\left(\varphi, r^{T}\right)} \frac{1}{\sigma^{T} \sqrt{2 \pi}} e^{\frac{-(z-2)^{2}}{2\left(\sigma^{T}\right)^{2}}} d z$

Total volatility decreases with trade if the covariance between shocks is negative and larger in absolute value than $\left(\sigma^{x}\right)^{2} / 2$. In such case, according to Equation (7), the probability of bankruptcy involves a threshold shock $\underline{z}^{T}\left(\varphi, r^{T}\right)$ that solves the following 
equation: $\underline{z}^{T}\left(p^{d} y^{d}+p^{x} y^{x}\right)-\left(y^{d}+y^{x}\right) / \varphi-\left(I+I^{x}\right)\left(1+r^{T}\right)=0$. The threshold shock of an exporter is lower than that of a non-exporter if $\mathrm{I}^{\mathrm{x}}\left(1+\mathrm{r}^{\mathrm{T}}\right)<\mathrm{I}\left[\left(\mathrm{r}-\mathrm{r}^{\mathrm{T}}\right)+(1+\mathrm{r}) \tau^{1-\alpha}\right]+(\tau-1) \mathrm{y}^{\mathrm{d}} \tau^{-\alpha} / \varphi$, i.e. if the fixed cost involved in exporting is not too high compared with the decrease in the fixed cost in the national production, and the increase in sales. If the above condition holds, and the total income variance of a company when it exports is lower than its domestic income variance, then the probability of bankruptcy of exporters will be lower than that of non-exporters ${ }^{7}$. The following Proposition summarizes the impact of volatility on the cost of trade:

Proposition 3: If the volatility shocks in the national and international market are negatively correlated ${ }^{8}$, trade can lead to a reduction of total income volatility, through market diversification. Trade can therefore reduce the firm's probability of bankruptcy if the firm diversifies its total income volatility, and if the fixed cost to export is not too high.

The intuition behind Proposition 3 is that trade can reduce financial risks but only if the income shocks are negatively correlated, and if it is not too costly to export compared to producing only domestically. Under these circumstances, by exporting the firm can reduce its probability of bankruptcy. Even if its probability of bankruptcy is lower, this does not mean that exporters obtain a lower interest rate than non-exporters. The bank charges in fact an interest rate $r^{T}$ to exporters, such that the expected repayment of the loan equals the repayment of a riskless loan, solving the following Equation:

$\left(1+r_{0}\right)\left(I+I^{\mathrm{x}}\right)=\left(1+\mathrm{r}^{\mathrm{T}}\right)\left(\mathrm{I}+\mathrm{I}^{\mathrm{x}}\right) \delta^{\mathrm{T}}\left(\varphi, \sigma^{\mathrm{T}}, \mathrm{r}^{\mathrm{T}}\right)+\mathrm{C}\left(\sigma^{\mathrm{T}}\right) \cdot\left(1-\delta^{\mathrm{T}}\left(\varphi, \sigma^{\mathrm{T}}, \mathrm{r}^{\mathrm{T}}\right)\right)$

\footnotetext{
${ }^{7}$ The probability of bankruptcy is lower because both the threshold shock and the total income volatility decrease under these two assumptions. These two conditions are sufficient conditions but not necessary conditions for trade to reduce the firm's probability of bankruptcy. A less restrictive necessary condition is:$$
\int_{-\infty}^{z^{T}} f_{i}^{d}(d z)-\int_{-\infty}^{\underline{z}^{T}} f_{i}^{T}(d z)>\int_{z^{T}}^{z^{x}} f_{i}^{T}(d z)
$$

${ }^{8}$ Hirsch and Lev (1971) also found that exports tend to stabilize firms' sales through market diversification.
} 
Having to borrow more, exporters might have a lower ratio of collateral over debt than non-exporters. Trade has therefore an ambiguous effect on the exporters' cost of external financing as it both decreases their probability of bankruptcy (under the assumptions of Proposition 3), which lowers the interest rate; while simultaneously increasing the debt, which raises the interest rate. Greenaway et al. (2006) have shown empirically that trade improves the financial position of firms. Since collateral is a decreasing function of volatility, it is plausible that exporters systematically have higher collateral than non-exporters. Then by Proposition 3, income diversification would decrease the exporters' interest rate, and trade would unambiguously reduce their costs of accessing external finance, improving their financial situation. This argument could provide a theoretical foundation for the outcome describe in Greenaway et al. (2006).

\section{Volatility and the incentive to trade}

We now turn to a related question: do firms with high national income volatility have more incentives to trade than firms with low national income volatility? Denote with $\Pi^{T}\left(\varphi, \sigma^{T}\right)$ the profits of exporters, with $\Pi\left(\varphi, \sigma^{d}\right)$ the profits of non-exporters, with $r^{T}$

the interest rate of exporters, and with $r^{d}$ the interest rate of non-exporters. Then the profit differential is given by the following Equation:

$$
\Pi^{\mathrm{T}}\left(\varphi, \sigma^{\mathrm{T}}\right)-\Pi\left(\varphi, \sigma^{\mathrm{d}}\right)=-\left(1+\mathrm{r}^{\mathrm{T}}\right) \cdot \mathrm{I}+\left(1+\mathrm{r}^{\mathrm{d}}\right) \cdot \mathrm{I}+\mathrm{p}^{\mathrm{x}} \mathrm{y}^{\mathrm{x}}-\frac{\mathrm{y}^{\mathrm{x}}}{\varphi}-\left(1+\mathrm{r}^{\mathrm{T}}\right) \cdot \mathrm{I}^{\mathrm{x}}
$$

Firms with high national income volatility have more incentives to trade than firms with low volatility if the profit differential is increasing with domestic income volatility. Differentiating Equation (8) with respect to domestic volatility leads to: $\frac{\partial\left(\Pi^{\mathrm{T}}-\Pi\right)}{\partial \sigma^{\mathrm{d}}}=\mathrm{I} \cdot \frac{\partial \mathrm{r}^{\mathrm{d}}}{\partial \sigma^{\mathrm{d}}}-\left(\mathrm{I}+\mathrm{I}^{\mathrm{x}}\right) \frac{\partial \mathrm{r}^{\mathrm{T}}}{\partial \sigma^{\mathrm{d}}}$. This implies that firms with high national income volatility have more incentives to trade than firms with low national income volatility if the following inequality holds 
$\mathrm{I} \frac{\partial \mathrm{r}^{\mathrm{d}}}{\partial \sigma^{\mathrm{d}}}>\left(\mathrm{I}+\mathrm{I}^{\mathrm{x}}\right) \frac{\partial \mathrm{r}^{\mathrm{d}}}{\partial \sigma^{\mathrm{d}}}$

In the absence of trade, an increase in volatility leads to an increase in the interest rate, $\frac{\partial r^{d}}{\partial \sigma^{d}}>0$, as shown in Proposition 1. However, this is not necessarily the case with trade if there is diversification in income shocks. We can observe two cases when firms export. First, if the total interest rate does not change for different degrees of national income volatility (i.e. if $\frac{\partial r^{T}}{\partial \sigma^{d}}=0$ ), then inequality (9) holds and firms with a high domestic income volatility have more incentives to trade than firms with low domestic income volatility. In this case, firms with high national income volatility are able to diversify their income shocks relatively more than low volatility firms. Exporters and nonexporters end up therefore having a similar total volatility, independently of the volatility of their domestic income volatility. For this reason more volatile firms have more incentives to trade. Second, even if the interest rate rises with domestic volatility for exporters (i.e. if $\frac{\partial r^{T}}{\partial \sigma^{d}}>0$ ), when there is diversification, the increase in the interest rate associated with increases in volatility is lower for exporters than for non-exporters (i.e. $\left.\frac{\partial r^{d}}{\partial \sigma^{d}}>\frac{\partial r^{T}}{\partial \sigma^{d}}\right)$. If this effect is sufficiently large as to counter balance the rise in the fixed cost necessary to export (i.e. if $\frac{\partial \mathrm{r}^{\mathrm{d}} / \partial \sigma^{\mathrm{d}}}{\partial \mathrm{r}^{\mathrm{T}} / \partial \sigma^{\mathrm{d}}}>\frac{\mathrm{I}+\mathrm{I}^{\mathrm{x}}}{\mathrm{I}}$ ), then firms with high domestic income volatility have more incentives to export than firms with low domestic income volatility. Proposition 4 summarizes the relationship between national income volatility and incentives to trade:

Proposition 4: Firms with high national income volatility have more incentives to trade than firms with low national income volatility provided that when exporting, their interest rate decreases more than proportionally to the increase in the fixed costs of production. 
Intuitively, before exporting, firms with low domestic income volatility can obtain a loan at a lower cost than firms with high domestic income volatility. This generates incentives for firms with low volatility to start exporting. However, for highly volatile firms, the prospective reduction in the total volatility is larger than for firms with low volatility, which in turn reduces their interest rates and encourages them to trade.

\section{Effects of a trade agreement lowering trade barriers between countries}

A trade agreement that reciprocally lowers trade barriers between countries can, on the one hand, reduce the variable costs of trade, and on the other, decrease the sunk entry cost. A decrease in the variable trade cost reduces the probability of bankruptcy of the exporters by decreasing the threshold shock. This leads to a decrease in the interest rate. The model suggests that the reduction in the cost of accessing external funding can induce a reduction in the firm's financial constraints. The decrease in the sunk costs has two effects. First, as in the case of a reduction in the variable cost to trade, it reduces the firm's probability of bankruptcy, leading to a decrease of the firm's interest rate. Second, it increases the incentives of high volatile firms to trade by reducing the left hand side of inequality (9).

Under the assumptions of Proposition 4, more volatile firms tend to trade more than firms with low volatility, when there is diversification of income shocks: trade reduces in fact the total volatility of these firms. The decrease in the total volatility leads to an increase in the expected profits for the potential entrants, since both the average industry volatility and the average probability of bankruptcy decrease. As in Melitz's (2003) model, the change in the expected profits affects the free entry condition and leads to a stationary equilibrium with less firms near the exit function $s(\varphi)=\sigma$. This mechanism, that is similar to a decrease in the fixed entry cost in Hopenhayn's (1992) model, produces a subsequent decrease in the exit function $s(\varphi)=\sigma$, which, as shown in Figure 5, implies that in the new equilibrium, the industry has on average a higher level of productivity and a lower level of average volatility.

\section{INSERT FIGURE 5 HERE}




\subsection{Testable implications}

From the analysis of our theoretical model, several testable implications emerge. First, the model suggests that controlling for productivity and collateral over debt, firms with high volatility have a higher probability of bankruptcy. It is consequently more costly for them to obtain external finance. Second, the model implies that there is a positive correlation between volatility and productivity for high levels of volatility, while there is no correlation for low levels. Highly volatile firms need in fact to be more productive to stay in the market. Third, the open economy model suggests that, through market diversification, exports tend to stabilize firms' total sales. Exporters' total income volatility will therefore be lower than their national income volatility. Finally, firms characterized by high national income volatility will have more incentives to start exporting than firms with low volatility. In the Sections that follow, we will test these implications using a panel of 9292 UK firms over the period 1993-2003.

\section{Data and summary statistics}

\subsection{The dataset}

We construct our dataset from profit and loss and balance sheet data gathered by Bureau Van Dijk in the Financial Analysis Made Easy (FAME) database. This provides information on companies for the period 1993-2003 ${ }^{9}$. It includes a majority of firms which are not traded on the stock market, or are quoted on other exchanges such as the Alternative Investment Market (AIM) and the Off-Exchange (OFEX) market ${ }^{10}$. Unquoted firms are more likely to be characterized by adverse financial attributes such as a short track record, poor solvency, and low real assets compared to quoted firms, which are typically large, financially healthy, long-established companies with good credit ratings.

The firms in our dataset operate in the manufacturing sector. We excluded companies that changed the date of their accounting year-end by more than a few weeks, so that data refer to 12 month accounting periods. Firms that did not have complete

\footnotetext{
${ }^{9}$ A maximum of ten years of complete data history can be downloaded at once for each firm.

${ }^{10}$ We only selected firms that have unconsolidated accounts: this ensures the majority of firms in our dataset are relatively small. Moreover, it avoids the double counting of firms belonging to groups, which would be included in the dataset if firms with consolidated accounts were also part of it.
} 
records on variables used in our regressions were also dropped. Finally, to control for outliers, we excluded observations in the $1 \%$ tails for each variable ${ }^{11}$. Our panel therefore comprises a total of 51668 annual observations on 9292 companies, covering the years 1993-2003. It has an unbalanced structure, with an average of 7 observations per firm. By allowing for both entry and exit, the use of an unbalanced panel partially mitigates potential selection and survivor bias.

\subsection{Summary statistics}

Summary statistics of the main variables used in our empirical analysis are presented in Table 1. Column 1 refers to the entire sample; column 2 and 3, to surviving and failed firms, respectively. As in Bunn and Redwood (2003), we define a firm as failed (bankrupt) in a given year if its company status is in receivership, liquidation, or dissolved $^{12}$. Columns 4 and 5 of Table 1 refer respectively to low and high volatility firms; and columns 6 and 7, to non-exporters at time $t$ - 1 that entered and did not enter export markets at $t$.

\section{INSERT TABLE 1 HERE}

As in Comin et al. (2006) and Comin and Philippon (2005), our main volatility measure is calculated as the standard deviation of the firm's total real sales growth, measured over a rolling window of 5 years. Specifically, denoting with Totalvol $_{i t}$ this standard deviation for firm $i$ at time $t$; with $s r g r_{i t}$, the growth rate of the real sales of firm $i$ at time $t$, and with $\mu_{i t}$, the average growth rate between $t-2$ and $t+2$, we have:

$$
\text { Totalvol }_{i t}=\left[\frac{1}{5} \sum_{\tau=-2}^{2}\left(\operatorname{srgr}_{i(t+\tau)}-\mu_{i t}\right)^{2}\right]^{1 / 2}
$$

\footnotetext{
${ }^{11}$ These cut-offs are aimed at eliminating observations reflecting particularly large mergers, extraordinary firm shocks, or coding errors. See Appendix 2 for more information on the structure of our panel and complete definitions of all variables used.

${ }^{12}$ Liquidation and receivership are two types of reorganization procedures, which can take place when a company becomes insolvent. In liquidation, the assets of the company are sold so as to meet the claims of creditors. In receivership, the receiver can decide whether it is in the creditors' interests to sell the company's assets. Generally, it is in the creditors' interests to liquidate if the liquidation value of the company exceeds its going concern value (Lennox, 1999b).
} 
We also provide measures of volatility only based on national sales growth and overseas sales growth, which we denote respectively with Nationalvol ${ }_{i t}$ and with Overseasvol $_{i t}{ }^{13}$.

Comparing total sales growth volatility at failed and surviving firms (columns 2 and 3), we can see that the former display a higher volatility (0.207) than the latter $(0.199)$. The difference between the two figures is marginally statistically significant (tstatistic: 1.69). In accordance with the first testable implication of our model, there is some evidence that failed firms are more volatile than their surviving counterparts. More formal tests of this hypothesis will be provided in the section that follows.

Focusing now on columns 2 and 3, with emphasis on productivity (TFP), which is calculated using the Levinsohn and Petrin (2003) method ${ }^{14}$, it appears that both high and low volatility firms display very similar levels of productivity (5.820 and 5.826, respectively). Yet the correlation between TFP and volatility is positive for highvolatility firms (0.0650) and negative for low-volatility firms (-0.0655). This seems to support our model's second prediction, according to which one should observe a positive correlation between idiosyncratic volatility and productivity for high levels of volatility only.

Next, in relation to our open economy model's predictions, we compare the firm's total, national, and overseas sales growth volatility, based on the entire sample (column 1). We can see that, as suggested by our model, the volatility of total sales growth $(0.1999)$ is lower than that of national sales growth $(0.238)$. The difference between the two means is strongly significant $(\mathrm{t}$-statistic $=29.86)$. Also considering that overseas sales display the highest volatility (0.482), this provides some preliminary support for the hypothesis that through market diversification, exports tend to stabilize total sales ${ }^{15}$.

\footnotetext{
${ }^{13}$ It should be noted that given the way in which we calculate volatility, this variable is not available for the years 1993, 1994, 2002, and 2003. For this reason, all regressions which contain our main measure of volatility are based on the sample 1995-2001.

${ }^{14}$ A key issue in the estimation of production functions is the correlation between unobservable productivity shocks and input levels. Profit-maximizing firms respond to positive productivity shocks by expanding output, which requires additional inputs; and to negative shocks, by decreasing output and input usage. Olley and Pakes' (1996) estimator uses investment as a proxy for these unobservable shocks. This could cause problems as any observation with zero investment would have to be dropped from the data. Levinsohn and Petrin (2003), by contrast, introduce an estimator which uses intermediate inputs as proxies, arguing that these (which are generally non-zero) are likely to respond more smoothly to productivity shocks.

${ }^{15}$ If we limit the sample to exporters, the volatility of total sales growth is given by 0.198 ; that of national sales growth, by 0.248 ; and that of overseas sales growth, by 0.479 .
} 
Finally, focusing on columns 6 and 7 of Table 1, we can see that starters display a much higher national sales volatility compared to non-starters (0.309 versus 0.193$)$. The difference between the two means is statistically significant (t-statistic $=7.63)$. Although this comparison is simply based on unconditional means, it provides some strong support for our model's last testable implication. More formal tests of all the implications of our model are provided in the next Section.

\section{Specifications and results}

\subsection{Are more volatile firms more likely to go bankrupt?}

In order to test the first implication of our model, namely that more volatile firms are more likely to fail, we will estimate a random-effects Probit specification of the following type:

$$
\begin{aligned}
& \operatorname{Pr}\left(\text { FAIL }_{i t}=1\right)=\Phi\left(\mathrm{a}_{0}+\mathrm{a}_{1} \text { size }_{i t}+\mathrm{a}_{2} \text { age }_{i t}+\mathrm{a}_{3} \text { group }_{i}+\mathrm{a}_{4} t f p_{i t}+\right. \\
& \left.+\mathrm{a}_{5} \text { Collateral }_{i f} \text { Debt }_{i t}{ }^{*}+\mathrm{a}_{6} \text { Totalvol } u_{i}+u_{j}+u_{t}\right)
\end{aligned}
$$

$F A I L_{i t}$ is a dummy variable equal to 1 if firm $i$ failed in year $t$, and 0 otherwise. $\Phi($.) denotes the standard normal distribution function. As typically done in the literature (see for instance Bunn and Redwood, 2003, and Disney et al, 2003), our Equation controls for firm's size, age, productivity, and for whether the firm is part of a group. In accordance with our model we also include the firm's collateral to debt ratio and the volatility of its total sales growth among the regressors. Since the average length of time between the final annual report of a failing company and its entry into bankruptcy is usually 14 months (Lennox, 1999a), our specification includes regressors evaluated at time $t$. Yet, all our results were robust to using lagged regressors. $u_{t}$, represents a full set of time dummies aimed at accounting for business cycle effects; and $u_{j}$, a full set of industry dummies $^{16}$.

\footnotetext{
${ }^{16}$ Firms are allocated to the following industrial groups: metals and metal goods; other minerals, and mineral products; chemicals and man made fibres; mechanical engineering; electrical and instrument engineering; motor vehicles and parts, other transport equipment; food, drink, and tobacco; textiles, clothing, leather, and footwear; and others (Blundell et al., 1992).
} 


\section{INSERT TABLE 2 HERE}

The estimates of Equation (10) are presented in column 1 of Table 2. As typically found in the literature, size and TFP have a negative effect on the firm's probability of failure. The coefficient associated with the ratio of the firm's collateral to total debt is poorly determined suggesting that this variable does not play a statistically significant effect on firm survival. In accordance with Proposition 1 in our model, the volatility of the firm's total sales growth is positively associated with the chances that the firm will go bankrupt: more volatile firms are therefore more likely to die.

As an alternative test of this first implication of the model, we make use of the Quiscore measure produced by Qui Credit Assessment Ltd., which assesses the likelihood of company failure in the 12 months following the date of calculation. The lower its Quiscore, the more risky the firm, and the higher its chances of failure. We estimate the following fixed-effects regression:

$$
\begin{aligned}
& \text { QUISCORE }_{i t}=\mathrm{a}_{0}+\mathrm{a}_{1} \text { size }_{i t}+\mathrm{a}_{2} \text { age }_{i t}+\mathrm{a}_{3} t f p_{i t}+ \\
& +\mathrm{a}_{4} \text { Collateral }_{i t} \text { Debt }_{i t}+\mathrm{a}_{5} \text { Totalvol }+u_{i}+u_{j}+u_{t}
\end{aligned}
$$

The results are presented in column 2 of Table 2 . TFP is positively associated with Quiscore, suggesting that more productive firms are less risky, and less likely to fail. Our collateral to debt ratio is also positively associated with Quiscore, indicating that the more collateral a firm has relative to its total debt, the less risky it is. Surprisingly, our size variable is negatively associated with Quiscore, suggesting that larger firms are more risky. Finally, our volatility measure displays a negative coefficient: more volatile firms are more risky, and therefore more likely to fail, which is in accordance with our Proposition 1.

As banks generally look at firms' credit ratings such as Quiscore when deciding the terms of the loans they make to firms, it is likely that they will charge higher interest rates to the riskiest firms. Thus, as predicted by our model, more volatile firms are more likely to fail, and to be charged higher interest rates by their lenders. 
4.2 Is there a positive correlation between productivity and volatility for highly volatile firms only?

The second main implication of our model is that there should be a positive correlation between productivity and volatility for highly volatile firms only. In order to test this implication, we construct the following two dummies: $L O W V O L_{i t}$, which is equal to one if firm $i$ 's total real sales growth volatility in year $t$ is in the lowest half of the distribution of the volatilities of all firms operating in the same industry as firm $i$ 's in year $t$, and 0 otherwise; and $H I G H V O L_{i t}$, which is equal to one if firm $i$ 's volatility in year $t$ is in the highest half of the distribution, and 0 otherwise. We then interact our volatility measure with the two dummies and estimate the following Equation, using a fixed-effects specification:

$$
T F P_{i t}=\mathrm{a}_{0}+\mathrm{a}_{1} \text { totalvol }_{i t} * L_{O W V O l_{i t}}+\mathrm{a}_{2} \text { totalvol }_{i t} * H I G H V O l_{i t}+u_{j}+u_{t}+e_{i t}
$$

The coefficient $a_{l}$ can be interpreted as the effect of volatility on TFP for firms with low volatility; and $a_{2}$, as the effect for firms with high volatility. The estimates are reported in column 1 of Table 3 . We can see that only $a_{2}$ is statistically significant. This suggests that volatility only affects the productivity of those firms characterized by a high volatility. This is consistent with our model's second prediction. Column 2 reports the results when firms are divided in three categories based on their volatility: there are three interaction terms: one for low-volatility firms, one for medium-volatility firms, and one for highvolatility firms ${ }^{17}$. Once again, there is a positive association between volatility and TFP only for high-volatility firms, which supports our model's second prediction.

\section{INSERT TABLE 3 HERE}

\subsection{Are more volatile firms more likely to start exporting?}

\footnotetext{
${ }^{17}$ In this case the interaction dummies are defined as follows: $L O W V O L_{i t}$ is equal to one if firm $i$ 's total real sales growth volatility in year $t$ is in the lowest $33 \%$ of the distribution of the volatilities of all firms operating in the same industry as firm $i$ 's in year $t$, and 0 otherwise; MIDDLEVOL $L_{i t}$ is equal to one if firm
} 
Lastly, our model predicts that it is those firms that display highest volatility of national sales growth that should have more incentives to start exporting. In order to test this prediction, we estimate the following random-effects Probit equation for the probability that a non-exporter at time $t-1$ becomes an exporter at $t$ :

$$
\begin{gathered}
S T A R T_{i t}=\mathrm{a}_{0}+\mathrm{a}_{1} \text { size }_{i t}+\mathrm{a}_{2} \text { age }_{i t}+\mathrm{a}_{3} t f p_{i t}+\mathrm{a}_{4} \text { group }_{i}+ \\
+\mathrm{a}_{5} \text { nationalvol }_{i t}+u_{j}+u_{t}+e_{i t}
\end{gathered}
$$

The dependent variable, $S T A R T_{i}$, is equal to one for those firms that exported at $t$, but not at $t-1$, and 0 otherwise. As in the regression for firm failure, our right-hand side variables include the firm's size, its age, and its TFP. To test our model's prediction, we have also added the volatility of the firm's national sales growth among our regressors. The results are presented in column 1 of Table 4 . We can see that larger firms are more likely to enter export markets, and that the volatility of national sales growth is also positively associated with the probability that the firm starts exporting. Yet, it should be noted that our previous measure of volatility, calculated over a rolling window of five years is based on the firm's national sales before and after entry in the foreign market. This could introduce bias in the regression. We therefore verify whether our results are robust to using two different measures of national sales volatility: the first is the standard deviation of the firm's real sales calculated over the five years preceding and including year $t$. The second one is calculated in a similar way but using all years preceding and including year $t$. The results based on these two alternative measures of volatility are presented in columns 2 and 3 of Table 4. We can see that in both cases, a higher volatility is still positively associated with a higher probability to start exporting. Thus, as predicted by the model, those firms displaying high volatility in their national real sales are also more likely to start exporting. In summary, the data seem to lend strong support tour model.

\section{INSERT TABLE 4 HERE}

$i$ 's volatility in year $t$ is in the middle $33 \%$ of the distribution, and 0 otherwise; and $H I G H V O L_{i t}$ is equal to one if firm $i$ 's volatility in year $t$ is in the highest $33 \%$ of the distribution, and 0 otherwise. 


\section{Conclusion}

We have constructed a dynamic monopolistic model with heterogeneous firms to study the links between firms' idiosyncratic uncertainty, the degree of financial constraints that they face, and their export market participation decisions. Our model, which can be seen as an extension of Melitz' (2003) model, where firm level volatility is included as an additional dimension of firm heterogeneity, predicts that more volatile companies are more likely to fail, need to be more productive to stay in the market, and are less likely to enter export markets. A further implication is that through market diversification, exports tend to stabilize firms' total sales. We have tested these predictions, using a panel of 9292 UK manufacturing firms over the period 1993-2003, and found strong support for our model. 


\section{APPENDIX 1: Proofs of Proposition 1 and of the Zero-Profit Condition}

\section{Proof of Proposition 1}

We want to show that given two firms ( $i$ and $j$ ) which only differ in their volatility (for example $\sigma_{i}>\sigma_{j}$ ), then the more volatile firm has a higher probability of bankruptcy than the less volatile company, i.e. $\delta_{i}>\delta_{j}$.

Let us denote with $f(d z)$ the distribution of shocks of firm $i$, and with $\mathrm{g}(d z)$ the distribution of shocks of firm $j$. Let $\hat{z}$ be the point where both distributions intersect. Since the firms have the same productivity level and interest rate, from the point of view of the bank, the threshold shock is the same for both firms, i.e. $\underline{z}\left(\varphi_{i}, r\right)=\underline{z}\left(\varphi_{j}, r\right)=\underline{z}$. As shown in Figure 1 , if $\hat{z}>\underline{z}$, then $\mathrm{A}>\mathrm{B}$ meaning that $\int_{-\infty}^{z} f d z>\int_{-\infty}^{z} g d z$, and therefore $\delta_{i}>\delta_{j}$

\section{INSERT FIGURE 1 HERE}

Focusing on Figure 2, if $\hat{z}<\underline{z}$, then the probability of bankruptcy can be expressed as $\delta_{i}=A+B+C$ for company $i$, and as $\delta_{j}=B+C+D$ for company $j$. If $\mathrm{A}>\mathrm{D}$, then $\delta_{i}>\delta_{j}$. The properties of the normal distribution imply that $A+B+C+F=B+D+C+E+F=1 / 2$, therefore $A=D+E$. Since we have assumed that $\underline{z}<1$, this leads to $E>0$, therefore $A>D$. Q.E.D.

\section{INSERT FIGURE 2 HERE}

\section{Proof of the Zero-Profit Condition}

The firm's expected profits are given by the following expression: $E_{t}\left(\Pi_{t+1}\right)=p(\varphi) y(\varphi)-\frac{y(\varphi)}{\varphi}-(1+r(\varphi, \sigma)) I=d(\varphi)-(1+r(\varphi, \sigma)) I$, where $d(\varphi)$ is the firm's revenue. The maximum interest rate the company is willing to pay is the interest 
rate, which make expected profits equal to 0 . We denote this interest rate with $\tilde{r}$, which satisfies: $1+\tilde{r}=d(\varphi) / I$. Note that if the company is charged the interest rate $\tilde{r}$, the threshold shock is $\underline{z}(\tilde{r})=1$, and the probability of bankruptcy is $\delta(\tilde{r})=1 / 2$. The minimum interest rate that the bank will charge is the riskless interest rate $r_{0}$. Therefore, $r \in\left[r_{0}, \tilde{r}\right]$. We want to show that there exists an unique $r^{*} \in\left[r_{0}, \tilde{r}\right]$ such that Equations (3) and (4) in the text. According to these Equations, the bank will issue funds at an interest rate such that the expected repayment from the loan is equal to the repayment of a riskless loan for firms with probability of bankruptcy $\delta(\varphi, \sigma, r)$; and collateral is a negative function of the firm's volatility. Thus, the following Equation holds:

$I\left(r^{*}-r_{0}\right)-\delta\left(r^{*}\right)\left[\left(1+r^{*}\right) I-C\right]=0$

Let us define $j_{1}(r)=I\left(r-r_{0}\right)$, and $j_{2}(r)=\delta(r)[(1+r) I-C]$. We want to show that these functions intersect at a unique point. Both $j_{1}(r)$ and $j_{2}(r)$ are increasing functions of $r$ in the interval $\left[r_{0}, \tilde{r}\right]$. We therefore have:

$$
\begin{array}{ll}
\frac{\partial j_{1}(r)}{\partial r}=I>0 & \text { and } \quad \frac{\partial j_{2}(r)}{\partial r}=\frac{\partial \delta(r)}{\partial r}[(1+r) I-C]+I \delta(r)>0 \quad \text { since } \\
\frac{\partial \delta(r)}{\partial r}=\left(\frac{I}{p \cdot y}\right) \frac{1}{\sqrt{2 \pi} \sigma} e^{-(\underline{z}-1)^{2} / 2 \sigma^{2}}>0 &
\end{array}
$$

Moreover, the second derivate of $j_{2}(r)$ with respect to $r$ is positive for $\underline{z}<1$ or its equivalent if $r<\tilde{r}$. This can be represented as:

$$
\begin{aligned}
& \frac{\partial^{2} j_{2}(r)}{\partial r^{2}}=\frac{\partial^{2} \delta(r)}{\partial r^{2}}[(1+r) I-C]+2 I \frac{\partial \delta(r)}{\partial r} \delta(r) \\
& \frac{\partial^{2} \delta(r)}{\partial r^{2}}=\left(\frac{I}{p \cdot y}\right)^{2} \frac{1}{\sqrt{2 \pi} \sigma} e^{-(\underline{z}-1)^{2} / 2 \sigma^{2}}\left(\frac{-\underline{z}+1}{\sigma^{2}}\right)
\end{aligned}
$$

with 
We know that at $r_{0}, j_{1}\left(r_{0}\right)=0<j_{2}\left(r_{0}\right)=\delta\left(r_{0}\right)\left[\left(1+r_{0}\right) I-C\right]$ when $\left(1+r_{0}\right) I>C$. On the other hand, $\quad j_{1}(\tilde{r})=I\left(\tilde{r}-r_{0}\right) \quad$ and $\quad j_{2}(\tilde{r})=\delta(\tilde{r})[(1+\tilde{r}) I-C(\sigma)]=\frac{1}{2}[d(\varphi)-C(\sigma)] . \quad$ It follows that at $\tilde{r}, j_{1}(\tilde{r})>j_{2}(\tilde{r})$ if $d(\varphi)>2 I\left(1+r_{0}\right)-C(\sigma)$. Therefore by the intermediate value function, there exists an unique $r^{*} \in\left[r_{0}, \tilde{r}\right]$ in which both functions intersect when $d(\varphi)>2 I\left(1+r_{0}\right)-C(\sigma)$, and Equation (14) holds. Now we have to show that the curve $j_{2}(\tilde{r})$ always intersects with the line $j_{1}(\tilde{r})$ from bellow, so that they never intersect at two points in the interval $\left[r_{0}, \tilde{r}\right]$ and there cannot be two possible interest rates for a given firm. This is equivalent to showing that:

$\frac{\partial j_{2}\left(r^{*}\right)}{\partial r}<\frac{\partial j_{1}\left(r^{*}\right)}{\partial r}$

or equivalently that $\left(\frac{I}{p \cdot y}\right) \frac{1}{\sqrt{2 \pi} \sigma} e^{-\left(\underline{z}\left(r^{*}\right)-1\right)^{2} / 2 \sigma^{2}} \cdot\left[\left(1+r^{*}\right) I-C\right]+I \delta\left(r^{*}\right)<I . \quad$ Since $\underline{z}\left(r^{*}\right)-1 \in(0,1)$ then $e^{-\left(\underline{z}\left(r^{*}\right)-1\right)^{2} / 2 \sigma^{2}}<1$. We also know that $\left(\frac{I}{p \cdot y}\right)<1$ and that the maximum value of $\delta\left(r^{*}\right)$ is $1 / 2$. Therefore our condition (A2) can be expressed as follows:

$I<\frac{1}{\sqrt{2 \pi} \sigma} \cdot\left[\left(1+r^{*}\right) I-C\right]+\frac{1}{2} I<\frac{1}{\sqrt{2 \pi} \sigma} \cdot\left[\left(1+r^{*}\right) I-C\right] . \quad$ This inequality holds if $\sigma>\sqrt{\frac{2}{\pi}} \frac{\left(1+r^{*}\right) I-C}{I}$.

There are two possible cases. First, if the collateral is such that $C=\left(1+r_{0}\right) I$, then there is no risk and the bank will set $r^{*}=r_{0}$. Second, if $C<\left(1+r_{0}\right) I$, the bank will set an interest rate $r^{*} \in\left(r_{0}, \tilde{r}\right)$ for those firms with $d(\varphi)>2 I\left(1+r_{0}\right)-C(\sigma)$. For firms with $d(\varphi)<2 I\left(1+r_{0}\right)-C(\sigma)$, the bank will have incentives to charge an interest rate that the 
firms will not have incentives to take, preferring to stay out of the market. Finally for firms with:

$d(\varphi)=2 I\left(1+r_{0}\right)-C(\sigma)$

the bank will charge $r^{*}=\tilde{r}$ and these firms' profit will be zero. Furthermore, we assume that the function $C(\sigma)$ is invertible. There exits therefore a function $s(\varphi)=\sigma$ that solves equation (A3), such that the firm is charged an interest rate leading to zero profits.

\section{INSERT FIGURE 4}

\section{Proof of the Stationary Equilibrium in autarky}

The Zero profit condition $\Pi(\varphi, s(\varphi))=0$ can be expressed as $\mathrm{d}(\varphi)=(1+\mathrm{r}(\varphi, \mathrm{s}(\varphi))) \mathrm{I}$. The free entry condition is $\bar{\Pi}(\bar{\varphi}, \bar{\sigma}) \cdot \mathrm{P}_{\text {in }}(\varphi, \mathrm{s}(\varphi)) / \bar{\delta}(\bar{\varphi}, \bar{\sigma})=\mathrm{f}_{\mathrm{e}}$. The average profits can be written as:

$\bar{\Pi}(\bar{\varphi}, \bar{\sigma})=\mathrm{d}(\bar{\varphi})-\left(1+\mathrm{r}(\bar{\varphi}, \bar{\sigma}) \mathrm{I}=\mathrm{d}(\varphi)\left(\frac{\bar{\varphi}}{\varphi}\right)^{1-\alpha}-\left(1+\mathrm{r}(\bar{\varphi}, \bar{\sigma}) \mathrm{I}=\mathrm{I}\left[\left(\frac{\bar{\varphi}}{\varphi}\right)^{1-\alpha}(1+\mathrm{r}(\varphi, \mathrm{s}(\varphi)))-(1+\mathrm{r}(\bar{\varphi}, \bar{\sigma})]\right.\right.\right.$

Substituting this expression into the free entry condition, we obtain the following Equation which implies a cutoff level:

$\mathrm{I}\left[\left(\frac{\bar{\varphi}(\varphi)}{\varphi}\right)^{1-\alpha}(1+\mathrm{r}(\varphi, \mathrm{s}(\varphi)))-(1+\mathrm{r}(\bar{\varphi}(\varphi, \mathrm{s}(\varphi)), \bar{\sigma}(\varphi, \mathrm{s}(\varphi)))] \cdot \mathrm{P}_{\mathrm{in}}(\varphi, \mathrm{s}(\varphi)) / \bar{\delta}(\bar{\varphi}(\varphi, \mathrm{s}(\varphi)), \bar{\sigma}(\varphi, \mathrm{s}(\varphi)))=\mathrm{f}_{\mathrm{e}}\right.$

The left hand of the equation is a decreasing function that goes to infinity when $\varphi$ goes to zero and goes to zero when $\varphi$ goes to infinity. 


\section{Appendix 2: Data}

Structure of the unbalanced panel:

\begin{tabular}{|l|l|l|l|}
\hline \hline $\begin{array}{l}\text { Number of } \\
\text { observations } \\
\text { per firm }\end{array}$ & $\begin{array}{l}\text { Number } \\
\text { of firms }\end{array}$ & Percent & Cumulative \\
\hline & & & \\
1 & 1306 & 14.06 & 14.06 \\
2 & 918 & 9.88 & 23.93 \\
3 & 870 & 9.36 & 33.30 \\
4 & 825 & 8.88 & 42.18 \\
5 & 752 & 8.09 & 50.27 \\
6 & 703 & 7.57 & 57.83 \\
7 & 650 & 7.00 & 64.83 \\
8 & 757 & 8.15 & 72.98 \\
9 & 1078 & 11.60 & 84.58 \\
10 & 1433 & 15.42 & 100.00 \\
\hline Total & 9292 & 100.00 & \\
\hline \hline
\end{tabular}

\section{Definitions of the variables used:}

$F A I L_{i t}$ : dummy variable equal to 1 if firm $i$ failed in year $t$, and 0 otherwise. We define a firm as failed (dead) in a given year if its company status is in receivership, liquidation, or dissolved.

Size $i t$ : logarithm of the firm's total real assets. Total assets are given by the sum of fixed (tangible and intangible) assets and current assets, where current assets are defined as the sum of stocks, work-in-progress inventories, trade and other debtors, cash and equivalents, and other current assets.

Sales: includes both UK and overseas turnover.

Collateral $_{i f} /$ Debt $_{i t}$ : the ratio between the firm's tangible assets and its total (long- and short-term) debt.

TFP it: $_{\text {: }}$ total factor productivity calculated using the Levinsohn and Petrin (2003) method. 
Group $_{i}$ dummy variable equal to 1 if the firm is part of a group, and 0 otherwise. A company is said to be part of a group if it is a subsidiary of one or more holding companies (UK or foreign) ${ }^{18}$.

Quiscore $_{i t}$ is given as a number in the range from 0 to 100. The lower its Quiscore, the more risky a firm is likely to be. The indicator is constructed taking into account a number of factors, including the presence of any adverse documents appearing against the company on the public file, and the timeliness of getting the accounts filed. However, the most important factors relate to the financial performance of the company as evidenced by its balance sheet and profit and loss accounts. The key financial items used include turnover, pre-tax profits, working capital, intangibles, cash and bank deposits, creditors, bank loans and overdrafts, current assets, current liabilities, net assets, fixed assets, share capital, reserves and shareholders funds. The underlying economic conditions are also taken into account.

$S T A R T_{i t}$ : dummy variable equal to 1 if firm $i$ exported a positive amount in year $t$, but not in year $t-1$, and 0 otherwise.

Totalvol $_{i t}$ : standard deviation of the firm's total real sales growth. The standard deviation is measured over a rolling window of 5 years.

Nationalvol $_{i t}$ : standard deviation of the firm's real national sales growth. The standard deviation is measured over a rolling window of 5 years.

Overseasvol ${ }_{i t}$ : standard deviation of the firm's real overseas sales growth. The standard deviation is measured over a rolling window of 5 years.

Prenationalvol $_{i t}$ : standard deviation of the firm's real sales calculated over the five years preceding and including year $t$.

Prenationalvol1 $_{i t}$ : standard deviation of the firm's real sales calculated over all years preceding and including year $t$.

$L O W V O L_{i t}$ : dummy variable equal to one if firm $i$ 's Totalvol in year $t$ is in the lowest $50 \%$ of the distribution of the Totalvols of all firms operating in the same industry as firm $i$ 's in year $t$, and 0 otherwise.

\footnotetext{
${ }^{18}$ Information about whether a firm is part of a group is only provided in the last year of observations available for each firm. We therefore assume that a firm which was part of a group or foreign owned in its last available year was part of a group or foreign owned throughout the period in which it was observed. Given the short sample that we analyze, this is a reasonable assumption.
} 


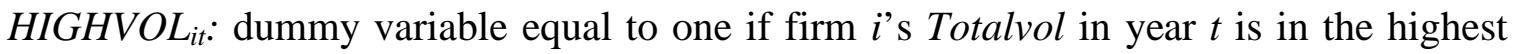
$50 \%$ of the distribution of the Totalvols of all firms operating in the same industry as firm $i$ 's in year $t$, and 0 otherwise.

Deflators: all variables are deflated using the aggregate GDP deflator.

\section{REFERENCES}

Blundell, R., Bond, S., Devereux, M., and F. Schiantarelli (1992). Investment and Tobin's Q: evidence from company panel data. Journal of Econometrics, 51, pp. 233-257.

Bunn, P. and V. Redwood (2003). Company accounts based modelling of business failures and the implications for financial stability. Bank of England Discussion Paper No. 210.

Comin, D., Groshen, E., and B. Rabin (2006). Turbulent firms, turbulent wages? National Bureau of Economic Research Working Paper No. 12032.

Comin, D. and Mulai, S. (2005). A theory of growth and volatility at the aggregate and firm level. NBER Working Paper no. 11503.

Comin, D. and Philippon, T. (2005). The rise in firm-level volatility: causes and consequences. NBER Working Paper no. 11388.

Cooley, T. and Quadrini, V. (2001). Financial markets and firm dynamics. American Economic Review, 91(5) pp. 1286-1310.

Disney, R., Haskel, J., and Y. Heden (2003). Entry, exit and establishment survival in UK manufacturing." Journal of Industrial Economics, 51, 91-112.

Dixit, A. and Stiglitz, J. (1977). Monopolistic competition and optimum product diversity. American Economic Review, 67(3), pp. 297-308.

Greenaway, D., Guariglia, A. and Kneller, R. (2006). Financial factors and exporting decisions. Mimeograph, University of Nottingham.

Grossman, G. and Helpman, E. (1991). Innovation and growth in the global economy. Cambridge Mass: MIT Press.

Hirsch, S. and B. Lev (1971). Sales stabilization through export diversification. Review of Economics and Statistics, 53(3), pp. 270-77. 
Hopenhayn, H. (1992). Entry, exit, and firm dynamics in long run equilibrium. Econometrica, 60(5), pp. 1127-1150.

Lennox, C (1999a). Identifying failing companies: a re-evaluation of the Logit, Probit and DA approaches. Journal of Economics and Business, 51, pp. 347-64.

Lennox, C. (1999b). Are large auditors more careful than small auditors?" Accounting and Business Research, 29, pp. 217-27.

Levinsohn, J. and A. Petrin (2003). Estimating production functions using inputs to control for unobservables. Review of Economic Studies, 70, pp. 317-342.

Melitz, M. (2003). The impact of intra-industry reallocations and aggregate industry productivity. Econometrica, 71(6), pp. 1695-1726.

Minton, B. and C. Schrand (1999). The impact of cash flow volatility on discretionary investment and the costs of debt and equity financing. Journal of Financial Economics, 54, pp. 423-60.

Olley, S. and A. Pakes (1996). "The dynamics of productivity in the telecommunications equipment industry." Econometrica, 64, 1263-1297. 
FIGURE 1: Quantifying the probabilities of bankruptcy of two firms facing different demand shocks when $\underline{z}<\hat{z}$

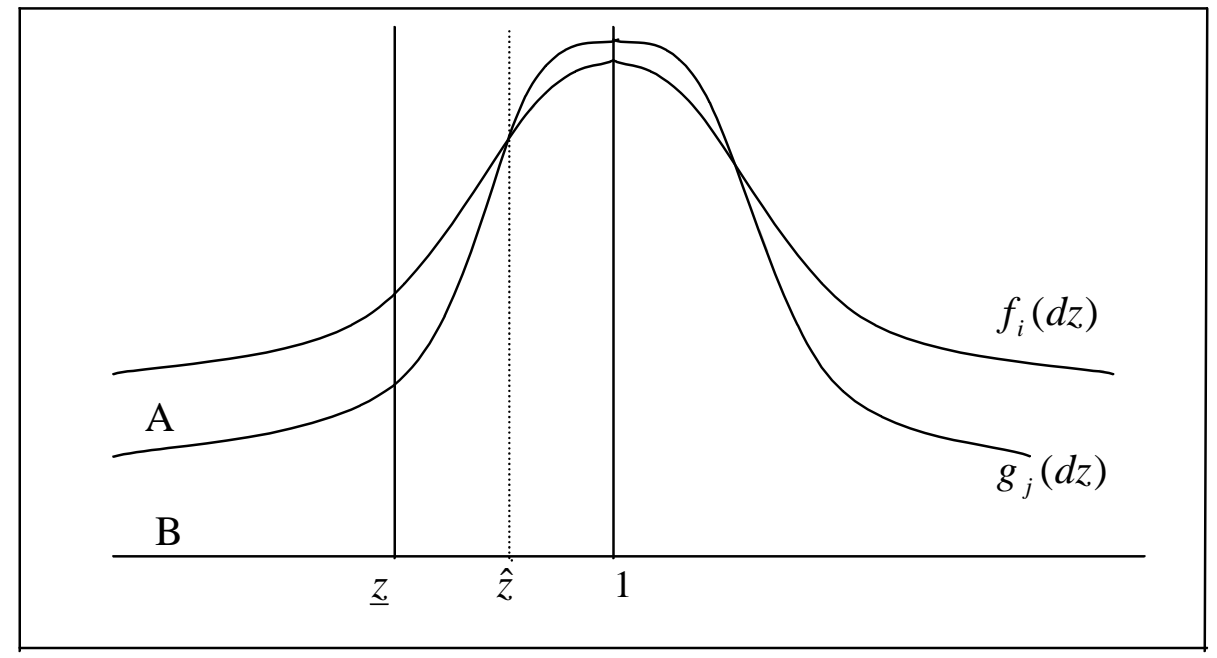


FIGURE 2: Quantifying the probabilities of bankruptcy of two firms facing different demand shocks when $\underline{z}>\hat{z}$

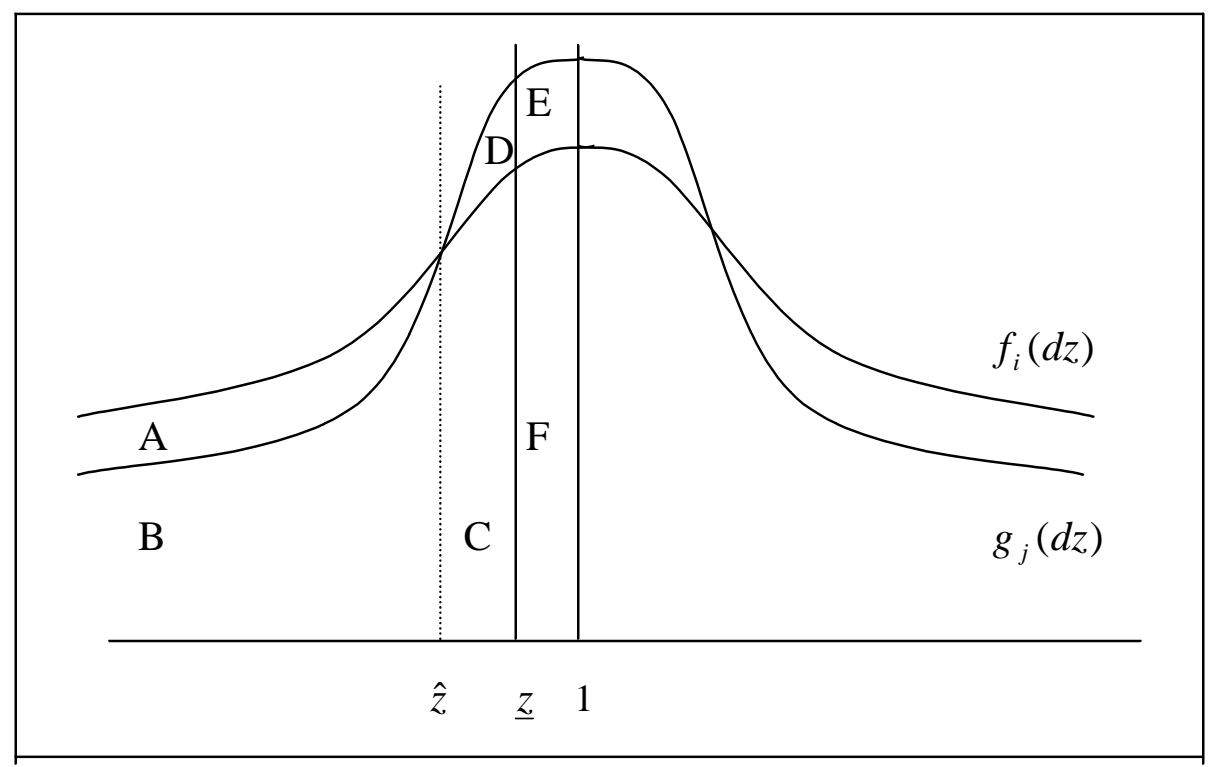


FIGURE 3: The relationship between volatility and productivity

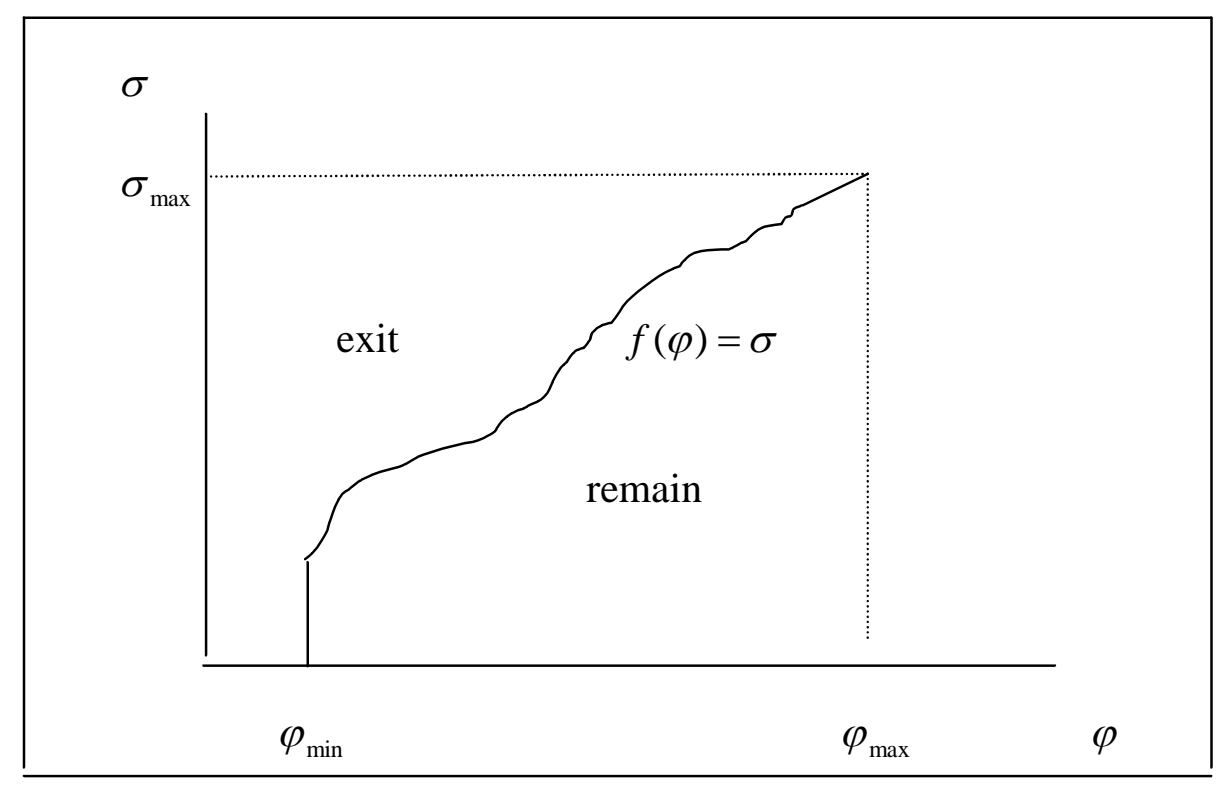


FIGURE 4: The zero-profit condition

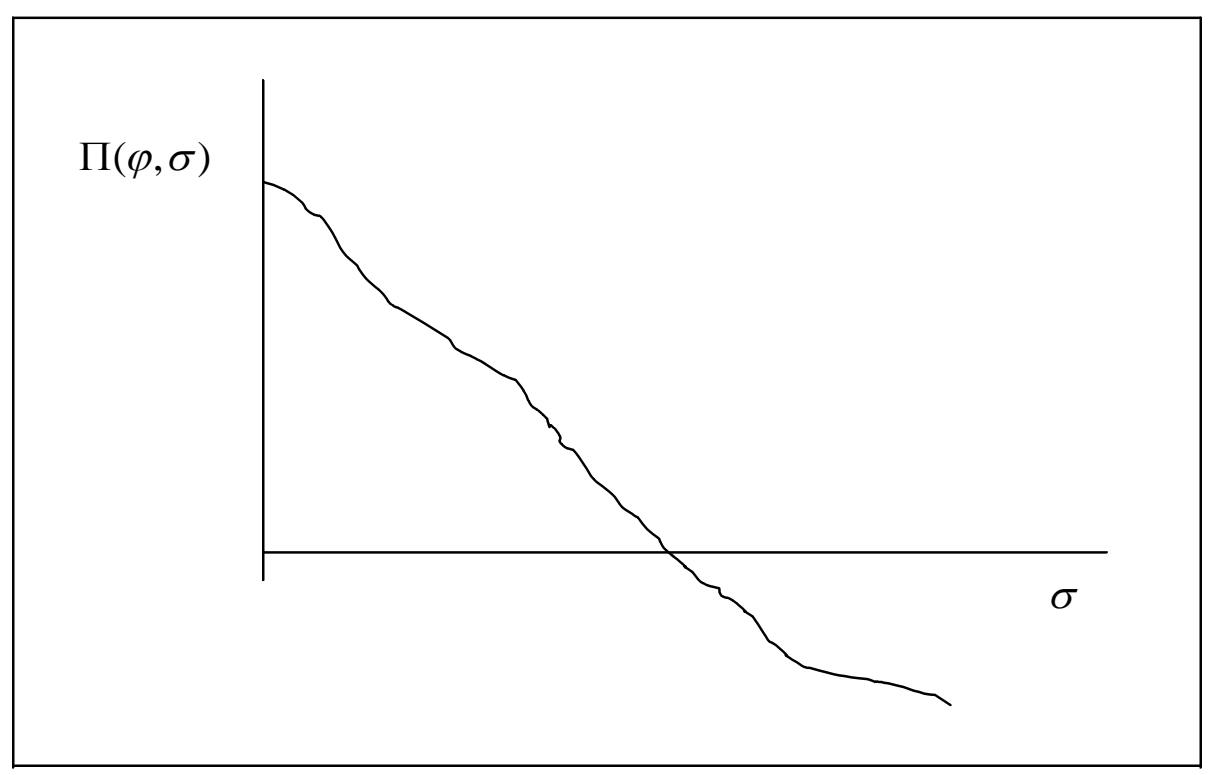


FIGURE 5: Effects of an agreement lowering trade barriers between countries

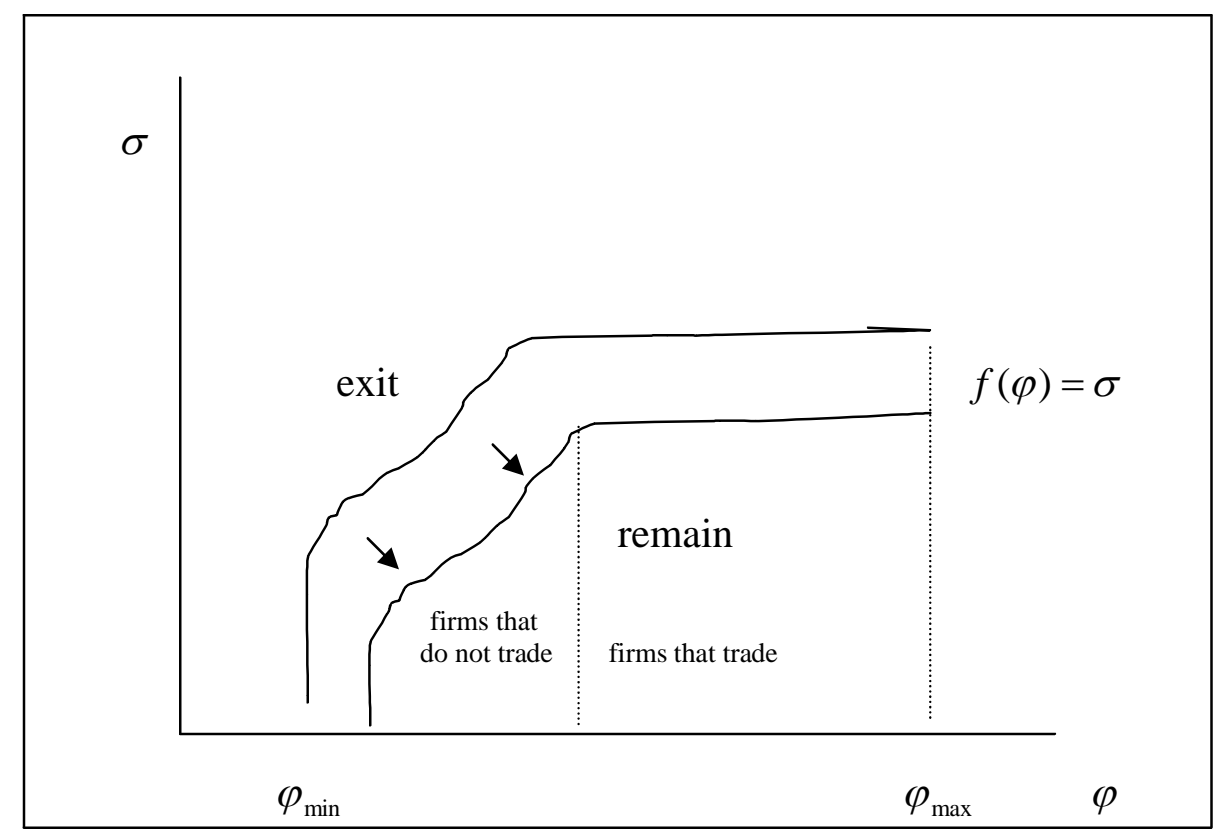


Table 1: Descriptive statistics

\begin{tabular}{|c|c|c|c|c|c|c|c|}
\hline & $(1)$ & (2) & (3) & (4) & (5) & (6) & (7) \\
\hline & $\begin{array}{c}\text { Total } \\
\text { sample }\end{array}$ & $\begin{array}{l}\text { FAIL }_{\text {it }} \\
\quad=0\end{array}$ & $\begin{array}{l}\text { FAIL }_{\text {it }} \\
\quad=1\end{array}$ & $\begin{array}{c}\text { LOWVOL }_{\text {it }} \\
=1\end{array}$ & $\begin{array}{l}\mathrm{HIGHVOL}_{\text {it }} \\
\quad=1\end{array}$ & $\begin{array}{c}\text { START }_{i} \\
{ }_{\mathrm{t}}=0\end{array}$ & $\begin{array}{c}\text { START }_{\text {it }} \\
=1\end{array}$ \\
\hline Size $_{i t}$ & $\begin{array}{l}8.834 \\
(1.41)\end{array}$ & $\begin{array}{l}8.881 \\
(1.42)\end{array}$ & $\begin{array}{l}8.341 \\
(1.15)\end{array}$ & $\begin{array}{l}9.033 \\
(1.34)\end{array}$ & $\begin{array}{l}8.972 \\
(1.35)\end{array}$ & $\begin{array}{l}8.311 \\
(1.35)\end{array}$ & $\begin{array}{l}8.739 \\
(1.40)\end{array}$ \\
\hline$A g e_{i t}$ & $\begin{array}{l}27.716 \\
(24.13)\end{array}$ & $\begin{array}{l}27.956 \\
(24.24)\end{array}$ & $\begin{array}{l}25.188 \\
(22.70)\end{array}$ & $\begin{array}{l}33.036 \\
(24.92)\end{array}$ & $\begin{array}{l}28.105 \\
(23.81)\end{array}$ & $\begin{array}{l}25.548 \\
(22.95)\end{array}$ & $\begin{array}{l}23.728 \\
(21.27)\end{array}$ \\
\hline$T f p_{i t}$ & $\begin{array}{l}5.650 \\
(2.44)\end{array}$ & $\begin{array}{l}5.738 \\
(2.48)\end{array}$ & $\begin{array}{l}4.760 \\
(1.84)\end{array}$ & $\begin{array}{l}5.826 \\
(2.40)\end{array}$ & $\begin{array}{l}5.820 \\
(2.40)\end{array}$ & $\begin{array}{l}5.188 \\
(2.27)\end{array}$ & $\begin{array}{l}5.489 \\
(2.51)\end{array}$ \\
\hline Group $_{i}$ & $\begin{array}{l}0.319 \\
(0.47)\end{array}$ & $\begin{array}{l}0.340 \\
(0.47)\end{array}$ & $\begin{array}{l}0.110 \\
(0.31)\end{array}$ & $\begin{array}{l}0.342 \\
(0.47)\end{array}$ & $\begin{array}{l}0.331 \\
(0.47)\end{array}$ & $\begin{array}{l}0.253 \\
(0.43)\end{array}$ & $\begin{array}{l}0.285 \\
(0.45)\end{array}$ \\
\hline Collateral $_{i} /$ Debt $_{i t}$ & $\begin{array}{l}1.765 \\
(3.52)\end{array}$ & $\begin{array}{l}1.781 \\
(3.56)\end{array}$ & $\begin{array}{l}1.632 \\
(3.11)\end{array}$ & $\begin{array}{l}1.888 \\
(3.76)\end{array}$ & $\begin{array}{l}1.587 \\
(3.28)\end{array}$ & $\begin{array}{c}2.00 \\
(4.07)\end{array}$ & $\begin{array}{l}1.699 \\
(2.63)\end{array}$ \\
\hline Quiscore $_{i t}$ & $\begin{array}{l}54.867 \\
(22.31)\end{array}$ & $\begin{array}{l}55.644 \\
(22.37)\end{array}$ & $\begin{array}{l}46.720 \\
(19.94)\end{array}$ & $\begin{array}{l}59.459 \\
(20.98)\end{array}$ & $\begin{array}{l}54.069 \\
(21.74)\end{array}$ & $\begin{array}{l}55.138 \\
(21.77)\end{array}$ & $\begin{array}{l}51.127 \\
(21.68)\end{array}$ \\
\hline Totalvol $_{i t}$ & $\begin{array}{l}0.197 \\
(0.19)\end{array}$ & $\begin{array}{l}0.199 \\
(0.19)\end{array}$ & $\begin{array}{l}0.207 \\
(0.17)\end{array}$ & $\begin{array}{l}0.092 \\
(0.04)\end{array}$ & $\begin{array}{l}0.306 \\
(0.22)\end{array}$ & $\begin{array}{l}0.190 \\
(0.21)\end{array}$ & $\begin{array}{l}0.238 \\
(0.31)\end{array}$ \\
\hline Nationalvol $_{i t}$ & $\begin{array}{l}0.238 \\
(0.27)\end{array}$ & $\begin{array}{l}0.237 \\
(0.27)\end{array}$ & $\begin{array}{l}0.258 \\
(0.30)\end{array}$ & $\begin{array}{l}0.131 \\
(0.17)\end{array}$ & $\begin{array}{l}0.346 \\
(0.31)\end{array}$ & $\begin{array}{l}0.193 \\
(0.23)\end{array}$ & $\begin{array}{l}0.309 \\
(0.42)\end{array}$ \\
\hline Overseasvol $_{i t}$ & $\begin{array}{l}0.482 \\
(0.50)\end{array}$ & $\begin{array}{l}0.479 \\
(0.50)\end{array}$ & $\begin{array}{l}0.546 \\
(0.53)\end{array}$ & $\begin{array}{l}0.370 \\
(0.42)\end{array}$ & $\begin{array}{l}0.593 \\
(0.54)\end{array}$ & $\begin{array}{l}0.389 \\
(0.31)\end{array}$ & $\begin{array}{l}0.771 \\
(0.84)\end{array}$ \\
\hline Observations & 51668 & 47177 & 4491 & 10576 & 10540 & 10388 & 681 \\
\hline
\end{tabular}

Notes: FAIL $L_{i t}$ : dummy variable equal to 1 if firm $i$ failed in year $t$, and 0 otherwise. $L O W V O L_{i t}$ / HIGHVOL $_{i t}$ : dummy variable equal to one if firm $i$ 's Totalvol in year $t$ is in the lowest (highest) $50 \%$ of the distribution of the Totalvols of all firms operating in the same industry as firm $i$ 's in year $t$, and 0 otherwise. $S T A R T_{i t}$ : dummy variable equal to 1 if firm $i$ exported a positive amount in year $t$, but not in year $t-1$, and 0 otherwise. Size $i_{i t}$ : logarithm of the firm's total real assets. Collateral $_{i f}$ Debt $_{i t}$ : the ratio between the firm's tangible assets and its total (long- and short-term) debt. TFP ${ }_{i t}$ : total factor productivity. Group dummy variable equal to 1 if the firm is part of a group, and 0 otherwise. Quiscore ${ }_{i t}$ is a measure of how risky the firm is. The lower its Quiscore, the more risky a firm is likely to be. Totalvol $i_{i t}$ : standard deviation of the firm's total real sales growth. The standard deviation is measured over a rolling window of 5 years. Nationalvol ${ }_{i t}$ : standard deviation of the firm's real national sales growth. Overseasvol ${ }_{i t}$ : standard deviation of the firm's real overseas sales growth. 
Table 2: Links between volatility and the probability of bankruptcy

\begin{tabular}{|c|c|c|}
\hline & $\begin{array}{c}\text { FAIL }_{\text {it }} \\
(1)\end{array}$ & $\begin{array}{c}\text { QUISCORE }_{i t} \\
\text { (2) }\end{array}$ \\
\hline$A g e_{i t}$ & $\begin{array}{l}0.005 \\
(1.65)\end{array}$ & $\begin{array}{l}0.064 \\
(0.46)\end{array}$ \\
\hline Size $_{i t}$ & $\begin{array}{l}-0.183 \\
(2.51)^{*}\end{array}$ & $\begin{array}{c}-4.623 \\
(7.28)^{* *}\end{array}$ \\
\hline Collateral $_{i} /$ Debt $_{i t}$ & $\begin{array}{l}0.001 \\
(0.02)\end{array}$ & $\begin{array}{c}2.030 \\
(19.71)^{* *}\end{array}$ \\
\hline$T f p_{i t}$ & $\begin{array}{c}-0.128 \\
(3.25)^{* *}\end{array}$ & $\begin{array}{c}3.189 \\
(16.30)^{* *}\end{array}$ \\
\hline Group $_{i}$ & $\begin{array}{c}-1.236 \\
(8.18)^{* *}\end{array}$ & \\
\hline Totalvol $_{i t}$ & $\begin{array}{c}0.762 \\
(2.53)^{*}\end{array}$ & $\begin{array}{c}-4.012 \\
(3.21)^{* *}\end{array}$ \\
\hline Observations & 9610 & 9934 \\
\hline
\end{tabular}

Notes: $t$-statistics are reported in parentheses. The estimates in column (1) were obtained using a randomeffects Probit specification; those in column (2), using a fixed-effects specification. * denotes significance at $5 \%$; ** denotes significance at $1 \%$. Also see Notes to Table 1. 
Table 3: Links between volatility and total factor productivity

\begin{tabular}{|c|c|c|}
\hline & $\mathrm{TFP}_{\text {it }}$ & $\begin{array}{l}\text { TFP }_{\text {it }} \\
(2)\end{array}$ \\
\hline Totalvol $_{i t} * L O W V O l_{i t}$ & $\begin{array}{l}0.028 \\
(0.13)\end{array}$ & $\begin{array}{l}-0.265 \\
(0.78)\end{array}$ \\
\hline $\begin{array}{l}\text { Totalvol }_{i t} * \mathrm{HIGHVOl}_{i t} \mathrm{MEDIUMVOL}_{i t} \\
\text { Totalvol }_{i t} * \mathrm{HIGHVOl}_{i t}\end{array}$ & $\begin{array}{l}0.222 \\
(3.02)^{* * *}\end{array}$ & $\begin{array}{l}-0.059 \\
(0.33) \\
0.170 \\
(2.17)^{*}\end{array}$ \\
\hline Observations & 16495 & 16495 \\
\hline
\end{tabular}

Notes: $t$-statistics are reported in parentheses. All estimates were obtained using a fixed-effects specification. In column (2), $\mathrm{LOWVOL}_{i t} / \mathrm{HIGHVOL}_{i t}$ are dummy variables equal to one if firm i's Totalvol in year $t$ is in the lowest (highest) $50 \%$ of the distribution of the Totalvols of all firms operating in the same industry as firm $i$ 's in year $t$, and 0 otherwise. In column (3), $L O W V O L_{i t}$ is equal to one if firm $i$ 's total real sales growth volatility in year $t$ is in the lowest $33 \%$ of the distribution of the volatilities of all firms operating in the same industry as firm $i$ 's in year $t$, and 0 otherwise; MIDDLEVOL $L_{i t}$ is equal to one if firm $i$ 's volatility in year $t$ is in the middle $33 \%$ of the distribution, and 0 otherwise; and $H I G H V O L_{i t}$ is equal to one if firm $i$ 's volatility in year $t$ is in the highest $33 \%$ of the distribution, and 0 otherwise. ${ }^{*}$ denotes significance at 5\%; ** denotes significance at $1 \%$. Also see Notes to Table 1. 
Table 4: Links between volatility and the probability to start exporting

\begin{tabular}{|c|c|c|c|}
\hline & $\begin{array}{c}\text { START }_{\text {it }} \\
\text { (1) }\end{array}$ & $\begin{array}{c}\text { START }_{\text {it }} \\
\text { (2) }\end{array}$ & $\begin{array}{c}\text { START }_{\text {it }} \\
(3)\end{array}$ \\
\hline$A g e_{i t}$ & $\begin{array}{l}-0.001 \\
(0.54)\end{array}$ & $\begin{array}{l}-0.001 \\
(0.38)\end{array}$ & $\begin{array}{l}-0.001 \\
(0.34)\end{array}$ \\
\hline Size $_{i t}$ & $\begin{array}{c}0.341 \\
(5.67)^{* *}\end{array}$ & $\begin{array}{c}0.272 \\
(5.00)^{* *}\end{array}$ & $\begin{array}{c}0.275 \\
(5.06) * *\end{array}$ \\
\hline$T f p_{i t}$ & $\begin{array}{l}-0.072 \\
(2.42)^{*}\end{array}$ & $\begin{array}{l}-0.043 \\
(1.67)\end{array}$ & $\begin{array}{l}-0.045 \\
(1.73)\end{array}$ \\
\hline Group $_{i}$ & $\begin{array}{l}-0.037 \\
(0.29)\end{array}$ & $\begin{array}{l}0.047 \\
(0.40)\end{array}$ & $\begin{array}{l}0.052 \\
(0.44)\end{array}$ \\
\hline Nationalvol $_{i t}$ & $\begin{array}{c}0.725 \\
(4.14)^{* *}\end{array}$ & & \\
\hline Prenationalvol $_{i t}$ & & $\begin{array}{c}0.724 \\
(3.60)^{* *}\end{array}$ & \\
\hline Prenationalvoll $_{i t}$ & & & $\begin{array}{c}0.730 \\
(3.42)^{* *}\end{array}$ \\
\hline Observations & 3299 & 3170 & 3170 \\
\hline
\end{tabular}

Notes: $t$-statistics are reported in parentheses. All estimates were obtained using a random-effects Probit specification. Prenationalvol $i_{i t}$ : standard deviation of the firm's real sales calculated over the five years preceding and including year $t$. Prenationalvoll ${ }_{i t}$ : standard deviation of the firm's real sales calculated over all years preceding and including year $t . *$ denotes significance at $5 \% ; * *$ denotes significance at $1 \%$. Also see Notes to Table 1. 